\title{
NOTES ON THE CARIBBEAN ORCHID FLORA. V. NEW SPECIES, COMBINATIONS AND RECORDS
}

\author{
JAMES D. ACKERMAN \\ Department of Biology, University of Puerto Rico, PO Box 23360 San Juan, PR 00931-3360, USA \\ ackerman@upracd.upr.clu.edu
}

\begin{abstract}
Three species of Orchidaceae are described as new to science: a Telipogon and a Lankesterella from the Dominican Republic and an Encyclia from Cuba. Telipogon niri is based on material collected by Donald Dod from the Cordillera Central A rare species, T. niri was previously recognized as Stellilabium minutiflorum (Kraenzl.) Garay, a distinct species from Central America. The generic name has changed due to unequivocal molecular evidence offered by Norris Williams, and the specific epithet honors Dr. Mark Nir, an avid student of Caribbean orchids. Lankesterella glandula is also based on material collected by Dod from the Cordillera Central. Thus far known only from the type collection, it is the second representative of the genus in Hispaniola. Encyclia monteverdensis is described from 19th century Charles Wright collections from Monte Verde, Cuba. The combination, Dendrophylax filiformis (Sw.) Carlsward \& Whitten, suffers as a later homonym and is replaced by the next available name in the new combination Dendrophylax monteverdi (Rchb. f.) Ackerman \& Nir. Cyclopogon miradorensis Schltr. is reported for the island of Dominica; Cranichis ricartii Ackerman is noted for the island of Guadeloupe; Cranichis ovata Wickstr. and Psilochilus macrophyllus (Lindl.) Ames are noted for Montserrat; and Trinidad is another locality for C. ovata. In addition, Eurystyles domingensis Dod and two Malaxis species are added to the Cuban flora: M. apiculata Dod and M. hispaniolae (Schltr.) L.O. Williams.
\end{abstract}

RESUMEN. Tres especies de Orchidaceae se describen como nuevas para la ciencia: un Telipogon y una Lankesterella de República Dominicana y una Encyclia de Cuba. Telipogon niri se basa en material recolectado por Donald Dod en la Cordillera Central. Una especie rara, T. niri había sido determinada como Stellilabium minutiflorum (Kraenzl.) Garay, una especie distinta de Centro América. El nombre del género ha cambiado debido a la evidencia molecular inequívoca presentada por Norris Williams, y el epíteto específico honra al Dr. Mark Nir, un ávido estudioso de las orquídeas del Caribe. Lankesterella glandula se basa también en material recolectado por Dod en la Cordillera Central. Hasta ahora se conoce solamente el ejemplar tipo, y es el segundo representante del género en la Isla Española. Encyclia monteverdensis se describe de ejemplares de Charles Wright recolectados en el siglo XIX en Monte Verde, Cuba. La combinación Dendrophylax filiformis (Sw.) Carlsward \& Whitten es un homónimo posterior y se reemplaza por el próximo nombre disponible en la nueva combinación Dendrophylax monteverdi (Rchb. f.) Ackerman \& Nir. Cyclopogon miradorensis Schltr. se registra en la isla Dominica; Cranichis ricartii Ackerman en la isla Guadalupe; Cranichis ovata Wickstr. y Psilochilus macrophyllus (Lindl.) Ames en Montserrat, y Trinidad es otra localidad de C. ovata. Además, Eurystyles domingensis Dod y dos especies de Malaxis se añaden a la flora de Cuba: M. apiculata Dod y M. hispaniolae (Schltr.) L.O. Williams.

Palabras clave / Key words: Orchidaceae, Orchid Flora, Encyclia, Lankesterella, Stellilabium, Telipogon, Cuba, Dominican Republic, Greater Antilles, Lesser Antilles

The sole species of Telipogon from the Caribbean was discovered by Donald Dod in the Dominican Republic and identified by Leslie Garay as Stellilabium minutiflorum (Kraenzl.) Garay, a species whose type hails from Costa Rica. Dressler (1999) pointed out that $S$. minutiflorum has been one of the most widely used names in Central America encompassing plants that might be different species, though the lack of good material makes taxonomic determinations difficult. Thus, $S$. minutiflorum has been the generally accepted name for the Dominican plants, although Nir (2000) noted some differences between the type (Costa Rica, Endres s.n., W) and the Dod collections.

After studying specimens myself, and comparing them to the illustration of the Endres collection 


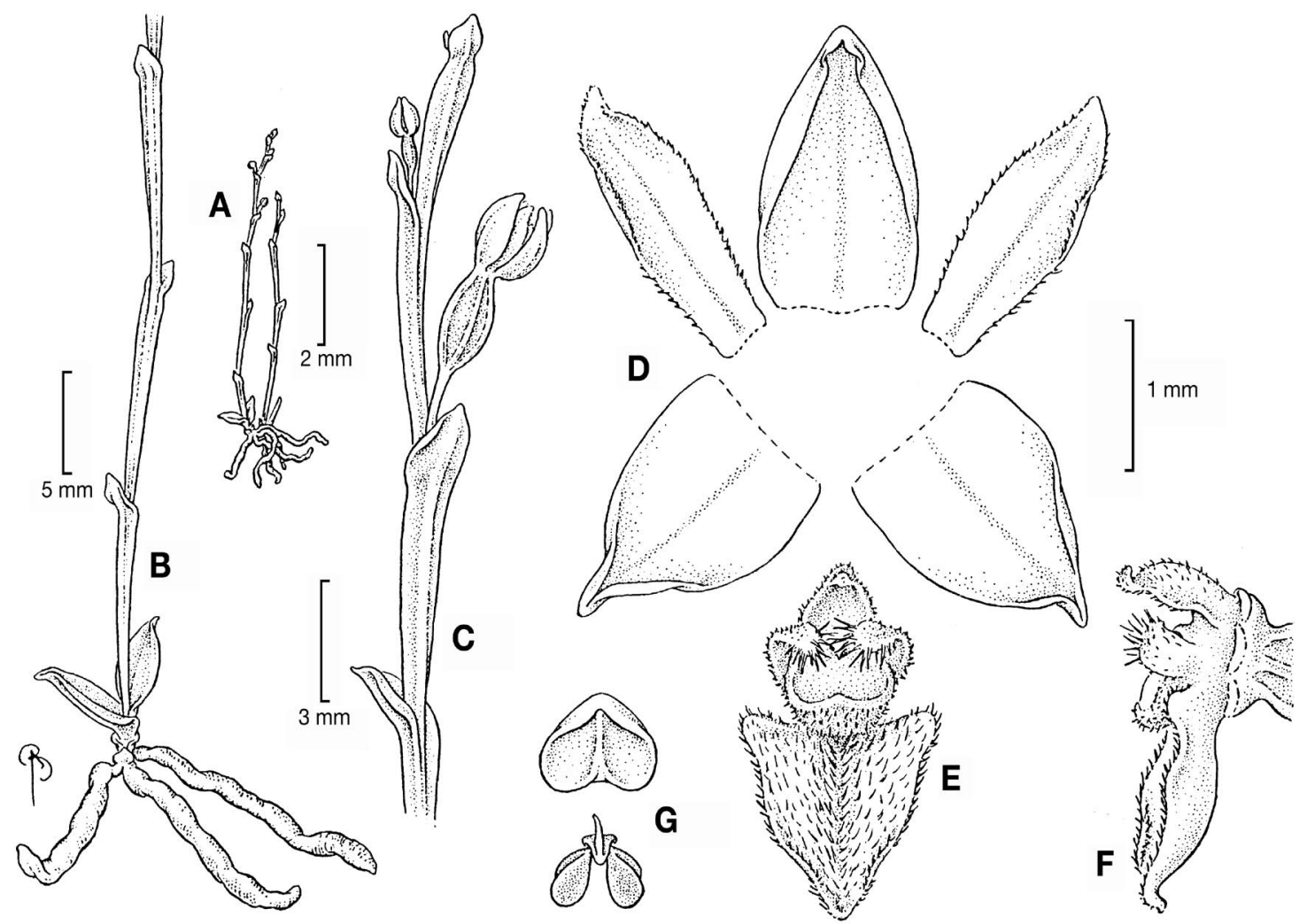

Figure 1. Telipogon niri Ackerman. A. Plant habit. B. Plant habit, lower half. C. Plant habit, upper half. D. Perianth, clockwise from top: dorsal sepal, petal, lateral sepal, lateral sepal, petal. E. Labellum and column, front view. F. Labellum and column, lateral view. G. Anther and pollinarium. Based on Liogier 13512 (NY) collected in the Dominican Republic. Illustrated by Bobbi Angell.

(AMES!) and a photographic slide of a Costa Rican plant shown to me by R. L. Dressler, I have concluded that the Dominican specimens are quite different from S. minutiflorum. Furthermore, the molecular systematics of Telipogon alliance by Williams et al. (in prep.) clearly shows that at least this group of Stellilabium is embedded in Telipogon, making the latter genus the appropriate taxon for this species.

Telipogon niri Ackerman, sp. nov.

TYPE: DOMINICAN RePUBlic. Bonao, Casabito, Sept. 1968, A.H. Liogier 13512 (= Dod 168) (holotype NY!).

FIG. 1

Rhachidi alata, labello hastato-ovato hispido ad basim breviter lobato, columnae trilobulatae lobulis lateralibus simplicisetibus, medio hispido.

Plants epiphytic, less than $10 \mathrm{~cm}$ tall. Roots few, fasciculate, thick for size of the plant, to $4 \mathrm{~cm}$ long, 1$2.5 \mathrm{~mm}$ diam. Stems rhizomatous, short, 2-4 mm long, covered by persistent leaf bases. Leaves 1-2, coriaceous, elliptic, cuspidate, acute, 4.5-5 mm long, $2 \mathrm{~mm}$ wide. Inflorescences erect; scape ancipitous, triquetrous, internodes 5-10 mm long, bracts abruptly divergent, ovate, acute, 1-2 mm long; racemes ancipitous, sparsely 2- to 4-flowered; floral bracts similar to scape bracts. Flowers minute, erect; pedicel slender, 2 $\mathrm{mm}$ long; ovary ellipsoid, prominently ribbed, 2.5 mm long; sepals greenish, 1-nerved, glabrous, entire, dorsal sepal concave, upper margins inrolled, ovate, acute to obtuse, $2 \mathrm{~mm}$ long, $1 \mathrm{~mm}$ wide, lateral sepals with upper margins slightly inrolled, broadly ovate, obtuse, slightly cuspidate, $1.75 \mathrm{~mm}$ long, $1.25 \mathrm{~mm}$ wide; petals greenish, 1-nerved, minutely ciliate, elliptic-oblanceolate, asymmetrically acute, $2 \mathrm{~mm}$ long, $0.75 \mathrm{~mm}$ wide; lip reddish to cinnamon brown, 
hispid adaxially, short-hastate, the basal lobes spreading, not extending beyond the base of the column, ovate, acute, $1.5 \mathrm{~mm}$ long, $1.3 \mathrm{~mm}$ wide; column pubescent, short, $0.9 \mathrm{~mm}$ long, lateral lobes ca. 0.5 $\mathrm{mm}$ long, arching above stigmatic cavity with simple apical bristles, median lobe hispidulous. Fruits on slender pedicels $1.8-2 \mathrm{~mm}$ long; capsules prominently ribbed, ellipsoid to subglobose, $1.8-5 \mathrm{~mm}$ long, to 3 mm diam.

The molecular systematics work of Williams et al. (in prep.) included T. niri. Their results show that the species is allied to T. minutiflorus Kraenzl. and other Central American species distinguished by a ribbonlike inflorescence rachis, trilobed column, fleshy stigma, and an adnate labellum (Dressler's Stellilabium sect. Taeniorhachis).

Telipogon niri differs from $T$. minutiflorus by having simple bristles on the lateral lobes of the column, and stubby lateral basal lobes of the labellum. On the other hand, T. minutiflorus has stellate bristles and the labellum has long basal lobes that flank the column nearly to the height of the anther. Furthermore, the general labellum shape of $T$. niri is more ovate than broadly oblong as in T. minutiflorus.

The type collection carries two collectors, Alain Liogier and Donald Dod. Dod's name and number is handwritten by Dod whereas Liogier's is typed on the label. When Liogier was at the Jardín Botánico Nacional "Rafael Moscoso" in Santo Domingo, it was his practice to put his own numbers on Dod's collections because Dod had not yet done so himself (Dod, pers. comm.).

Distribution: Dominican Republic: Prov. Monseñor Nouel, Cordillera Central.

ECOLOGY: Plants are epiphytes on trees overhanging rivers in wet montane, broadleaf forests at about $1200-1250 \mathrm{~m}$. Fruit set is good; the flowers are perhaps autogamous. Plants are quite rare. I had visited the original collection site of this plant with Donald Dod in 1995 but we failed to find any specimens.

Etymology: The specific epithet honors Dr. Mark Nir, a successful Dermatologist whose thick skin has been bitten by the orchid bug, causing him to suffer a severe case of the fever. Delirious, he undertook and completed the first comprehensive treatment of the
Caribbean orchid flora since Cogniaux's Symbolae Antillanae and has helped me in numerous ways in my efforts to publish the Orchidaceae treatment for the Flora of the Greater Antilles.

Lankesterella glandula Ackerman, sp. nov.

TYPE: DOMINICAN REPUBLIC. La Harme [sic] above San José de Ocoa on branches of old trees in virgin forest, alt. 2200 m, 23 Jan 1976, D. Dod s.n. (holotype SEL!).

FIG. 2

Inflorescentia floris solae, scapo sepalisque glandulosis, vix folia superantibus, labelli epichilo ovato, acutato.

Plants small, caespitose epiphytes. Roots few, fasciculate, fleshy, villous, $10 \mathrm{~mm}$ long, $1.5 \mathrm{~mm}$ diam. Stems abbreviated, concealed by roots and leaf bases. Leaves 10, in a basal rosette, sessile to broadly petiolate; petioles when present to $4 \mathrm{~mm}$ long; blades membranaceous, ciliolate, lanceolate, elliptical or oblanceolate, acute to acuminate, 12-17 mm long, 4-6 $\mathrm{mm}$ wide. Inflorescences slender, single-flowered; scape glandular, extending beyond the leaves, to 17 $\mathrm{mm}$ long, $0.2 \mathrm{~mm}$ diam. below, inflating to $0.5 \mathrm{~mm}$ just below the flower; floral bract irregularly crenulate-ciliate, ovate, caudate, $7.5 \mathrm{~mm}$ long, 4-4.5 mm wide, dorsal mid rib sparsely glandular pubescent. Flowers large for size of plant; ovary sessile, stout, 2 $\mathrm{mm}$ long; dorsal sepal adaxially glandular, conduplicate, 1-nerved, narrowly oblong, acute to acuminate, 6-8.5 mm long, 1.2-1.5 mm wide, lateral sepals broadly attached to column foot, basally connate, forming a gibbose, mentum $1 \mathrm{~mm}$ deep, 1-nerved, lanceolate, acuminate, 7-9 $\mathrm{mm}$ long to tip of mentum, 1.2-1.5 mm wide; petals free, glabrous, entire, 3nerved, somewhat obliquely oblanceolate, acuminate, $6 \mathrm{~mm}$ long, $1.2 \mathrm{~mm}$ wide; lip basally concave and adnate to the column foot, glabrous, entire, pandurate, 7-8.5 mm long, hypochile 5-nerved, 1.5-1.6 mm wide, isthmus 3-nerved, $1 \mathrm{~mm}$ wide, epichile ovate, acute, $4 \mathrm{~mm}$ long from the isthmus, 1.7-2.5 mm wide; column arcuate, $2-2.5 \mathrm{~mm}$ long, filament slender, arcuate, $1 \mathrm{~mm}$ long, anther lanceolate, acuminate, 2.5 $\mathrm{mm}$ long, stigma apical, pressed against anther. Fruits obovoid, ca. $7 \mathrm{~mm}$ long, $3 \mathrm{~mm}$ diam.

Lankesterella glandula is easily distinguished from L. alainii by the former being glandular rather than 


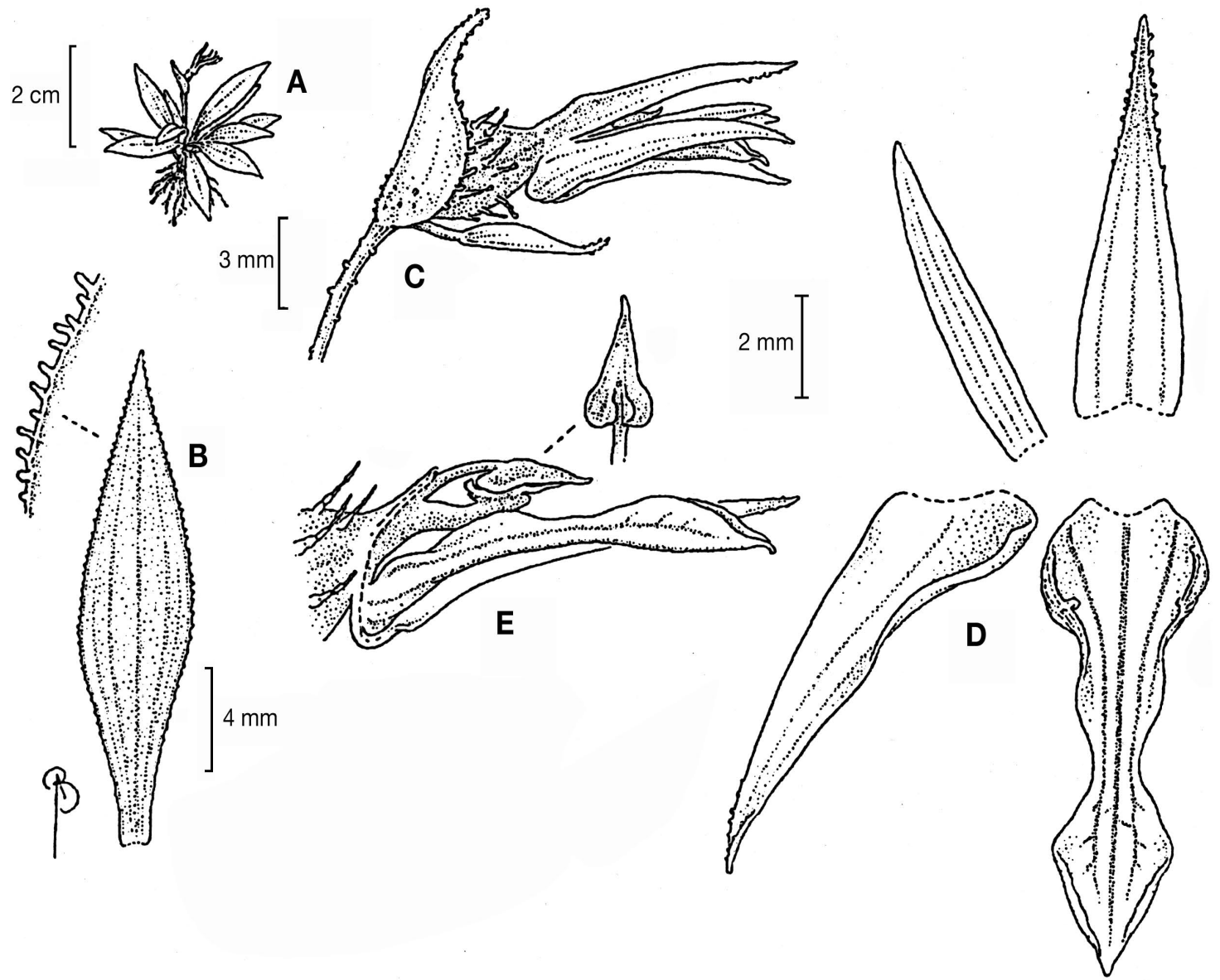

Figure 2. Lankesterella glandula Ackerman. A. Plant habit. B. Leaf. C. Inflorescence and flower, lateral view. D. Perianth, clockwise from top: dorsal sepal, labellum, lateral sepal, petal. E. Flower, lateral view with petals and one lateral sepal removed. Based on D. Dod s.n. (SEL) collected from the Dominican Republic. Illustrated by Bobbi Angell.

villous. Furthermore, the labellum has an acute apex rather than a rounded one. Most, if not all other Lankesterella are conspicuously pubescent, usually as villous as L. alainii. According to Nir's (2000) classification, L. glandula should be under Lankesterella section Lankesterella.

Dod made his collection in 1976. I had visited the region in the mid 80's and again in the mid 90's and most of the area is quite denuded.

Distribution: Dominican Republic: Prov. Peravia; Cordillera Central.

Ecology: Epiphytic in a broadleaf cloud forest. Elevation $2200 \mathrm{~m}$. Rare. Autogamous by virtue of the column arching downward bringing the apical stigma in direct contact with the anther. Flowering: Jan; fruiting: Jan.

ETYMOLOGY: The specific epithet refers to the glandular scape and adaxial surface of the sepals.

The genus Encyclia in Cuba is quite complex and Marta A. Díaz and I make no claim that our studies of the genus for the Flora of the Greater Antilles have resolved all questions regarding the delimitation of species. This following one, though, is quite distinctive.

Encyclia monteverdensis M. A. Díaz \& Ackerman, sp. nov.

TYPE: CUBA. [Prov. Guantánamo] prope villam Monte Verde dictam, Cuba orientali, Jan-Jul 1859, $C$. Wright 1489 (holotype: AMES 73736; isotypes: AMES 73735, K-L).
FIG. 3 


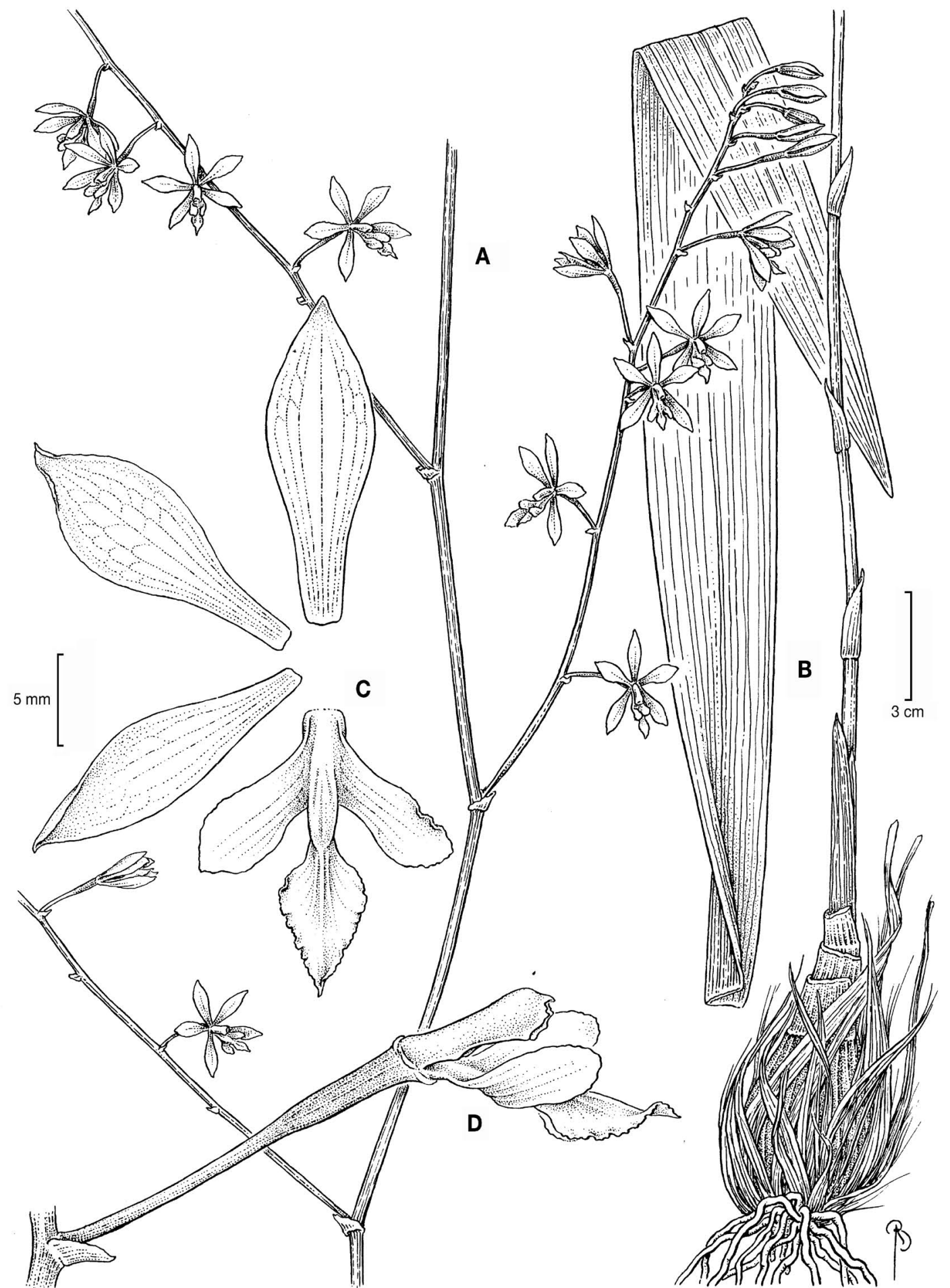

Figure 3. Encyclia monteverdensis M. A. Díaz \& Ackerman. A. Inflorescence. B. Plant habit with leaf detached. C. Perianth parts, counterclockwise from top: dorsal sepal, petal, lateral sepal, labellum. D. Flower, side view with sepals and petals removed. Based on type collection, C. Wright 1489 (AMES). Illustrated by Bobbi Angell. 
Encyclia monteverdensis M. Díaz \& Ackerman ab Encyclia oxypetala (Lindl.) Acuña petalis spathulatooblanceolatis, acutis, labelli lobo medio longiore (7.5-8 mm), undulato crispatoque, pseudobulbis majoribus, necnon ab Encyclia ochrantha (A. Rich.) Withner labelli lobo medio longiore quam lato, apiculato, bene distincta.

Plants robust caespitose, epiphytes. Roots white, numerous, produced from rhizome and base of pseudobulbs, $1.5-3 \mathrm{~mm}$ diam. Stems with short, stout rhizomes; pseudobulbs ovoid, subtended by scarious bracts shredded with age, to $7 \mathrm{~cm}$ long, $4.5 \mathrm{~cm}$ diam. Leaves 1-3, from apex of pseudobulbs, erect, coriaceous, oblong-lanceolate, acute-acuminate, to $42 \mathrm{~cm}$ long, $4 \mathrm{~cm}$ wide. Inflorescences terminal, erect, stout; peduncle to $85 \mathrm{~cm}$ long, $7 \mathrm{~mm}$ diam. near base, bracts progressively more distant, scarious, tightly sheathing half their length, upper half acuminate and slightly divergent from peduncle, to $26 \mathrm{~mm}$ long; panicle sparsely and diffusely branched, at least $30 \mathrm{~cm}$ long, branches 16-26 cm long, many-flowered. Flowers resupinate; sepals oblanceolate, dorsal sepal acute, 16.5-17.5 mm long, $5 \mathrm{~mm}$ wide, lateral sepals slightly oblique, acuminate-cuspidate, 17-18 mm long, 5$5.5 \mathrm{~mm}$ wide; petals spatulate to unguiculate, acute, sometimes apiculate, 16-17 mm long, 5-6.5 mm wide; labellum basally adnate to column for 1-2 mm, deeply three-lobed, 14.5-15 mm long, lateral lobes erect, flanking the column, oblong-falcate, rounded, 7-8 $\mathrm{mm}$ long from claw to apex, 2-3.5 mm wide, isthmus $2 \mathrm{~mm}$ long, 0.7-0.8 mm wide, mid lobe cuneate, ovate-elliptic, acute to acuminate, apiculate, 7.5-8 mm long, 4-4.5 mm wide, margin crisped, apex rolled to appear awn-like for $1 \mathrm{~mm}$; column straight, clavate, obscurely auriculate, 6-7.5 mm long; pedicelate ovary slender, 19-21 mm long. Fruits unknown.

Based on the form of the labellum, this species is closely related to $E$. oxypetala, but one may distinguish the two by the robust plants of E. monteverdensis which have very large pseudobulbs. Furthermore, the flowers of E. monteverdensis have perianth parts that are much wider, and the mid lobe is very obviously undulate-crispate. The plant habit of $E$. monteverdensis and the form of the sepals and petals are reminiscent of E. ochrantha A. Richard, but the mid lobe of the labellum in the latter is broader than long and the apex is acute rather than awn-like as in E. monteverdensis.
The type locality, Monte Verde, is an area of high endemism in Cuba. Thus far, this species is only known from the Wright's type collection of which we have seen three sheets. Given that this is a large Encyclia and we have not seen any other specimens other than the type material, we have little hope that Encyclia monteverdensis is thriving today.

Distribution: Cuba: Prov. Guantánamo; Macizo de Sagua Baracoa.

ECOLOGY: Encyclia monteverdensis is an epiphyte but that is about all we can guess. As was the practice in the mid 19th century, Charles Wright did not make detailed collection notes.

Etymology: Named for the type locality, Monte Verde, Guantánamo Province.

\section{A NEW COMBINATION}

The story of Dendrophylax filiformis (Sw.) Carlsward \& Whitten is a horrifying one. The basionym, Epidendrum filiforme Sw. was first confused with Campylocentrum fasciola (Lindl.) Cogn. in the mid 19th century and also with Dendrophylax porrectus (Rchb. f.) Carlsward \& Whitten in the 20 th century. Floristic treatments until very recently have criss-crossed their identities, which has only been compounded by the need to get them in the right genera. Recent molecular work on neotropical Angraecinae (Carlsward et al. 2003), unequivocally showed that Swartz's epithet should be transferred to Dendrophylax.

The eagle eye of Mark Nir, though, discovered that the Carlsward \& Whitten combination had already been made in 1898 by Fawcett in "A provisional list of the indigenous and naturalised flowering plants of Jamaica". Fawcett had attributed the combination to Bentham, who, having been dead for ten years at the time, was unable to defend himself. After Mark Nir notified me of the earlier combination, I decided to dig deep into the origin of Fawcett's name because of the long history of confusion surrounding the epithet. Fawcett placed Aeranthes in parenthesis below his combination and the only Aeranthes filiformis on record is by Grisebach (1864) in "Flora of the British West Indian Islands". Grisebach provided a detailed description and cited three specimens from Jamaica 
(McNab s.n., Purdie s.n., Wilson s.n.) and one from Trinidad (Bradford s.n.). The description and all four specimens (K!), match that of the earlier name, Campylocentrum fasciola. Unfortunately, Grisebach also cited Swartz and Lindley's combinations of filiformis in Limodorum and Angraecum, respectively. This error may have been the original source of confusion between the two species. Because Grisebach was no doubt basing his description on the material he had seen rather than that of Swartz, Grisebach's Aeranthes filiformis should be regarded as a new species, not a new combination. Thus, Aeranthes filiformis Griseb. and Dendrophylax filiformis (Griseb.) Benth. ex Fawc. should be regarded as synonyms of Campylocentrum fasciola Lindl.

This of course makes Dendrophylax filiformis (Sw.) Carlsward \& Whitten a later homonym. The next available name is the following:

Dendrophylax monteverdi (Rchb.f.) Ackerman \& Nir, comb. nov.

Aeranthes monteverdi Rchb.f, Flora 48: 279. 1865; Campylocentrum monteverdi (Rchb.f) Rolfe, Orchid Rev. 11: 247. 1903; Harrisella monteverdi (Rchb.f) Cogn. in Urb., Symb. Antill. 6: 687. 1910; Type: CubA: C. Wright 1497 (holotype $\mathrm{W}$ !; isotypes $\mathrm{NY}$ !, K!, K-L!).

Epidendrum filiforme Sw., Prodr. 126. 1788; Limodorum filiforme (Sw.) Sw., Nova Acta Regiae Soc. Sci. Upsal. 6: 80. 1799; Campylocentrum filiforme (Sw.) Cogn. ex Kuntze, Revis. Gen. P1. 3(2): 298. 1898; Harrisella filiformis (Sw.) Cogn. in Urb., Symb. Antill. 6: 687. 1910; Campylocentrum filiforme (Sw.) A. D. Hawkes, Phytologia 3: 248. 1950, nom. superfl.; Dendrophylax filiformis (Sw.) Carlsward \& Whitten, Int. J. P1. Sci. 164: 50. 2003, non Dendrophylax filiformis (Griseb.) Benth. ex Fawc.; Type: HisPaniola: Swartz s.n. (holotype BM!, isotype G!).

Ironically, I had earlier pointed out how Campylocentrum filiforme (Sw.) Cogn. ex Kuntze was the correct name for plants commonly known as C. monteverdi (Rchb.f) Rolfe (Ackerman 1995), but now that we know the species should be placed in Dendrophylax, we are forced to return to Reichenbach's name.

\section{NEW RECORDS}

Our knowledge of the Caribbean orchid flora has increased dramatically over the last few decades as botanists have explored ecological, systematic and floristic problems. While the Flora of the Greater Antilles project continues at a steady pace, major floras (Ackerman 1995, Nir 2000), smaller scale florulas (Feldmann and Barré 2001), and checklists have been published. Herein we add a few new records for various islands of the Caribbean.

\section{CUBA}

Eurystyles domingensis Dod, Moscosoa 1: 43. 1977.

Basis for concept: protologue and accompanying illustration and an isotype: DomINICAN REPUBLIC: Villa Altagracia, confluencia del Río Haina y de Río Duey, elev. 250 m, 15 Sept 1976, D.D. Dod 475 (isotypes AMES!, SEL!).

Cuban records: Cuba Orientali, 1860, C. Wright 1482 (MO!); Orientali, prope villam Monte Verde dictam, Jan-Jul 1859, C. Wright 1482 (AMES!); Oriente, La Prenda, 30 Dec 1920, Hioram 4162 (NY!).

The Cuban specimens cited above were previously identified as E. ananassocomos (Rchb. f.) Schltr., a species that may be confined to Jamaica. The Hioram collection was the basis for the Cuban record reported by Acuña (1939) and Sauget y Barbier (1946). I have examined this plant and the Wright specimens carefully and compared the flowers with those of Jamaican material (Syme s.n., J.P. 2283, NY!) and the Dod isotype at AMES. I conclude that all are more akin to E. domingensis than E. ananassocomos. Dietrich $(1988,1992)$ reported two other collections of E. ananassocomos from Santiago de Cuba but I have not been able to verify their identities.

Malaxis hispaniolae (Schltr.) L. O. Williams, Caldasia 5: 14. 1942.

Basis for concept: protologue, and the following paratypes: Dominican RePublic. Near Constanza, elev. 1200 m, Jun 1910, Türckheim 3457 (NY!); Barahona, elev. 500 m, Nov 1910, Fuertes 734 (NY!). Cuban record: Cuba. Prov. Oriente, 1860, $C$. Wright 1696 (BR!, MO!).

The Wright specimens were previously determined as Microstylis umbellulata (= Malaxis umbelliflora 
Sw.) and Malaxis spicata Sw. but they clearly are distinguished from it by the larger flowers, and the broad, auriculate labellum with a ciliolate margin. Furthermore, the inflorescence is racemose, rather than a tight subumbel as in the Cuban and Jamaican specimens of $M$. umbelliflora.

Malaxis apiculata Dod, Moscosoa 4: 174. 1986.

Basis for concept: protologue and accompanying illustration, and the following paratypes: DOMINICAN Republic. Ciénaga de la Culata, Constanza, elev. 1500-1600 m, 28 Nov. 1969, A. H. Liogier 17075 (NY!); Monteada Nueva, Caña Brava, Polo area, elev. 1200-1300 m, 26 Feb. 1969, A. H. Liogier $14260 a(\mathrm{NY}$ !).

Cuban records: Cuba. Prov. Oriente, Loma del Gato, 8 Dec. 1859, Wright 613 (AMES!); Prov. Oriente, 1856-1857, Wright 613 (AMES!); Prov. Oriente [Santiago de Cuba]: Loma San Juan (Gato), Jul. 1922, León \& Clément 10399 (MT!); Loma Cardero, south of Pico Turquino, elev. 3800 ft., 31 Jul. 1935, Roig, Acuña \& Bucher 6623 (NY!); Prov. Oriente [Santiago de Cuba]: Pico Turquino, south slopes, elev. 150-300 m, 20-21 Jul. 1940, W. Seifriz 1031 (US!); Prov. Oriente, Loma del Gato, Sierra Maestra, Jul. 1944, Alain 364 (AMES!); Prov. Oriente: Pico de La Bayamesa, north slope, elev. 4900-5200 ft., 16-19 Jul. 1955, Harvard Course in Tropical Botany (Schultes, Barclay, Beaman, Freeberg, Lee) 606 A (AMES!); Prov. Oriente: Pico de La Bayamesa, north slope, elev. 4900-5200 ft., 16-19 Jul. 1955, Harvard Course in Tropical Botany (Schultes, Barclay, Beaman, Freeberg, Lee) 604 (AMES!); Prov. Oriente: Pico de La Bayamesa, north slope, elev. 4900-5200 ft., 16-19 Jul. 1955, Harvard Course in Tropical Botany (Schultes, Barclay, Beaman, Freeberg, Lee) 749 (AMES!).

Dod's illustration, Fig. 16, is mislabeled as Malaxis megalantha Dod. The Cuban collections are from Loma del Gato and the southern side of Pico Turquino. The specimen from lower elevations (150$300 \mathrm{~m}$, Seifriz 1031) of Turquino has smaller flowers than what I have seen in the Dominican Republic and also for what was reported by Dod. However, plants much further up slope (ca. $1150 \mathrm{~m}$, Roig 6623, NY!) have flowers that are more typical in size.
DOMINICA

Cyclopogon miradorensis Schltr., Repert. Spec. Nov. Regni Veg. 21: 332. 1925.

Basis for concept: original description and drawing of type (Mexico. Veracruz, Mirador, $900 \mathrm{~m}$ elev., $J$. A. Purpus 92) at AMES, but see discussion below. Dominica ReCORD: Dominica. Heuters de la Réserve Caraibe. Bois de Gommier. Forêt dense et humide, elev. 800 m, 22 Apr. 1946, H. et M. Stehlé s.n. (US!). This is the first record of Cyclopogon miradorensis in the Lesser Antilles. It is also known from Puerto Rico, Dominican Republic, Jamaica, Cuba and the type locality, Mexico.

Dod (1989) was the first to report this species for the Antilles. Since then, I have collected Cuban (Ackerman et al. 3231), Jamaican (Ackerman \& Meléndez-Ackerman 2876), Dominican plants (Ackerman \& Thomas 2079) as well as Puerto Rican material (Ackerman 2570, Ackerman \& Meléndez 2678, Ackerman \& Angell 3007) and they are the same (all at UPRRP).

The Antillean plants are very similar to the drawings of the $C$. miradorensis type sent to AMES by Mansfeld prior to World War II. Unfortunately, these drawings were not made under the supervision of either R. Schlechter or Mrs. Schlechter (G. RomeroGonzález, pers. comm. 1993). There are some differences among the drawings, the protologue and our specimens. The labellum apex in the drawing is rounded and subapiculate whereas it is obscurely trilobed in both Antillean specimens and the protologue. Furthermore, our plants have sparsely pubescent ovaries that turn glabrous or nearly so as the fruits mature. The Mansfeld drawing and the protologue indicate glabrous ovaries. These discrepancies suggest that Greater Antillean plants may be a different species, but I am unwilling to make such a move without seeing good material of $C$. miradorensis from the type locality or nearby.

Cyclopogon miradorensis has been reported from a number of countries in Central and South America. Hamer (1982) reported the species from Nicaragua but the Caribbean plants differ from Hamer's in that the leaves are smaller, the lamina base is rounded and not cuneate, the petioles are very slender, and the perianth parts are approximately one third the size. 
Nir for the Latin descriptions. I am also grateful to Norris Williams and the staff at FLAS for providing logistic support during my sabbatical leave from the University of Puerto Rico, Bobbi Angell for the illustrations, and the curators and staff of the herbaria cited herein for specimen loans. This work has been supported by the National Science Foundation grant DEB-9505459.

\section{LITERATURE CITED}

Ackerman, J.D. 1995. An orchid flora of Puerto Rico and the Virgin Islands. Mem. New York Bot. Gard. 73: 1203.

Carlsward, B.S., W.M. Whitten \& N.H. Williams. 2003. Molecular phylogenetics of neotropical leafless Angraecinae (Orchidaceae): reevaluation of generic concepts. Int. J. Pl. Sci. 164: 43-51.

Dod, D.D. 1989. Orquídeas (Orchidaceae) nuevas para la Española y otras notas: II. Moscosoa 5: 235-249.

Dressler, R.L. 1993. Field guide to the orchids of Costa Rica and Panama. Cornell University Press, Ithaca.
Dressler, R.L. 1999. A reconsideration of Stellilabium and Dipterostele. Harvard Pap. Bot. 4: 469-473.

Dunsterville, G.C.K. \& L.A. Garay. 1979. Orchids of Venezuela. An illustrated field guide. A-G. Botanical Museum of Harvard University, Cambridge, Massachusetts.

Fawcett, W. 1898. A provisional list of the indigenous and naturalised flowering plants of Jamaica. Aston W. Gardner \& Co., Kingston.

Feldmann, P. \& N. Barré. 2001. Atlas des orchidées sauvages de la Guadeloupe. Patrim. Natur. 48: 1-228.

Grisebach, A.H.R. 1864. Flora of the British West Indian Islands. Lovell Reeve \& Co., London.

Hamer, F. 1982. Orchids of Nicaragua, Part 1. Icon. P1. Trop., fasc. 7.

Nir, M. 2000. Antillanae Orchidaceae. DAG Media Publishing, New York.

Salazar, G.A. 1990. Cyclopogon comosus (Rchb. f.) Burns-Balogh \& Greenwood. Plate 10. In: E. Hágsater \& G.A. Salazar (eds.). Orchids of Mexico, part 1. Icon. Orchid., fasc 1. Asociación Mexicana de Orquideología, México. 